\title{
Legal Consequences for Parties That Conduct Defaults In Verbal Contracts
}

\author{
Enni Martalena Pasaribu \\ \{ennipasaribu@gmail.com\} \\ Doctor of Law, Universitas Jayabaya, Jakarta, Indonesia
}

\begin{abstract}
Verbal contracts are often conducted. Unfortunately, verbal contracts are prone to defaults. This article discusses the strength of verbal contract, its legality based on the Civil Code, and the legal consequences that bind the parties who conduct defaults. Normative juridical approach was employed using justice theory and literature review. Primary, secondary and tertiary legal materials were used to complement the secondary data obtained through literature and data of Medan District Court Decision Number: 750 / Pdt.G / 2018 / PN.Mdn. The results showed that the defendants did defaults, where the plaintiffs' rights were not fulfilled by the defendants within the verbal contracts as the defendants denied the contracts. Therefore, the judges rejected plaintiffs' lawsuit. Verbal contracts are legally valid and do not violate the Law Number 1320 of Code of Civil Law which states that the requirements of a valid contracts include agreement that binds two parties, capability in making an agreement, a specific problem, and a non-prohibited reason. The plaintiffs proved in the court that the verbal contract made between plaintiffs and the defendants was valid and legal based on witnesses' statements and documents. However, board of judges rejected the suit due to the absence of written agreement.
\end{abstract}

Keywords: Verbal Contract; Plaintiffs; Defendants; Default

\section{Introduction}

The Civil Code is a source of formal law as well as a source of material law for treaty law in force in Indonesia. Agreements are specifically regulated in the Civil Code, Book III, Chapter II concerning "Agreements Born from Contracts or Agreements" and Chapters V to Chapter XVIII which regulate legal principles and legal norms of agreements in general, as well as norms agreement law norms that have special characteristics which are better known as agreements named (Harefa \& Tuhana, 2016). The agreement issues an agreement between two people who make it, in the form of an agreement it can be in the form of a series of words containing promises or abilities that are spoken or written (Subekti, 2003). Agreements can be made in writing or by means of oral, and not rare agreement made in silence - silence. Verbal agreements often occur in social life, and are often not realized, but an agreement has been reached (Harefa \& Tuhana, 2016).

Book III of the Civil Code Article 1313 states that "an agreement is an act whereby one or more persons bind themselves to one or more other persons". Based on some of the meanings of the agreement above, it can be concluded that in an agreement it can be in the form of a written or oral agreement, there are two or more parties, who mutually agree. Where one party is obliged to carry out the provisions of the agreement and one of the other parties gets something from the results of the agreement that has been agreed. This means that in carrying 
out verbal agreements that occur in social life, they are often not realized, but there has been an agreement. Making an agreement in oral form is still valid, as long as it has fulfilled the legal requirements of the agreement stated in Article 1320. Based on this, the research questions are as follows: "how is the legal force orally? What is the suitability of an oral agreement according to the Civil Code? what are the legal consequences for the party who defaults in the verbal agreement?"

The word default comes from the Dutch language, which means bad performance (wanbeeher), which means bad management; wanddad (bad deeds) (Yahman, 2014). Default is not fulfilling or negligent in carrying out obligations as specified in the agreement made between the creditor and the debtor (Salim, 2008). Default or non- fulfilment of promises can occur either intentionally or unintentionally (Miru, 2007). If the debtor (debtor) does not do what he promised then said he did " in default. "He is negligent or negligent or breaks his promise (Subekti, 2003). In general, default is the implementation of obligations that are not timely or carried out inappropriately. The debtor is mentioned and is in default, if he is negligent in carrying out the achievements in the agreement, so that it is "late" from the specified schedule or in carrying out an achievement that is not "properly or properly" (Yahman, 2014)"

An oral agreement is an agreement that has been made and agreed upon by the parties orally. This agreement is not the same as a written contract that spells out its terms in a document or deed. Article 1320 of the Criminal Code (the legal terms of the agreement) does not require that an agreement be made in writing, so that an oral agreement is also binding and valid. Article 1338 states that "all agreements made legally valid as law for those who make them, an agreement cannot be withdrawn other than by agreement of both parties, or for reasons which the law states are sufficient for it. An agreement must be executed in good faith. The oral agreement contains a promise that expresses the stated will and is considered a constitutive element of the binding power of the agreement. A new agreement is formed if there is an encounter or agreement between promises made by one party to another (Syaifuddin, 2012).

\section{Research Methods}

The research method used by researchers in this journal is a normative juridical approach using justice theory and library methods. The research stages use primary legal materials, secondary legal materials, and tertiary legal materials to complete secondary data obtained through the literature.

\section{Results and Discussion}

\section{The Legal Power of the Oral Agreement}

An agreement will be born when an agreement or agreement is reached between the two parties who are making an agreement, namely regarding the main things that are the object of the agreement. The word of agreement is an agreement between the understanding and the will between the two parties. It is stated in Article 1338 Book III of the Civil Code which states the principle of freedom of contract in making an agreement. According to Article 1233 of the Civil Code, "Every engagement is born either as an agreement or because of laws - laws. "The engagement that is born from the agreement can be made through the agreement of the parties who make the agreement. In Article 1313 of the Civil Code, an agreement is an act by which 
one or more people bind themselves to one or more other people. Thus, the agreement publishes an engagement between the two parties who make it or it can also be said that the agreement is the source of the engagement in addition to other sources. furthermore, in Article 1338 paragraph (3) of the Civil Code an agreement must be based on the principle of good faith. Good faith can be divided into subjective good faith and objective good faith. Subjective good faith is whether the person concerned himself is aware that his actions are contrary to good faith, while objective good faith is if public opinion considers such actions to be contrary to good faith.

Some of the conditions for agreements that are generally accepted but are regulated outside of Article 1320 of the Civil Code, are as follows (Prasetyo, 2017):

a. The agreement must be made in good faith, meaning that both parties to the agreement must carry out the contents of the agreement voluntarily and without coercion, and in good faith who really want to carry out the contents of the agreed agreement.

b. The agreement must not conflict with applicable customs, meaning that the contents of the agreement are not allowed to conflict with the prevailing customs in the community, must not conflict with existing conditions in society.

c. The agreement must be made based on the principle of propriety, meaning that the agreement that has been agreed must follow the principle that does not conflict with the provisions in force in the community, must not violate the rights of the community.

d. The agreement must not violate the public interest, meaning that the contract made is not justified in conflict with the interests that exist in the community, must not cause harm to the community.

According to Badrulzaman (2001), in an agreement there are several principles that apply, including:

a. Principle Freedom of Contract. Is one of the A 's as very important in contract law. This freedom is the embodiment of free will, the emission rights of a s ation humans. A $\mathrm{s}$ as it is based on the Civil Code Article 1338, which is an agreement made legally valid as law for those who make it.

b. Principles of Consensualism. Article 1320 of the Civil Code, $\mathrm{d}$ i mention explicitly that the agreement between the parties is a condition of the validity of the agreement and in Article 1338, mentioned "all agreements. " The words of the chapter in 1338 and 1320 shows that each person is given the opportunity to express his desire that he feels good to create the agreement. A s as it is closely connected with the A 's as freedom have an agreement.

c. Principles of Faith. It is a principle that shows someone who enters into an agreement with another party, fosters trust between the two parties that each other will keep his promise, in other words will fulfil his achievements in the future.

d. The Principle of Binding Strength. The binding of an agreement is not only limited to what is agreed upon but also to several other elements as long as it is desired by habit and moral propriety.

e. The Principle of Legal Equality. This principle places the parties in equality, there is no difference, even though there are differences in wealth, position, nation, and others. Each party must see this equality and require both parties to respect each other as God's creation.

f. Balance Principle. This principle requires both parties to fulfil and carry out the agreement. This principle is a continuation of the principle of equality.

g. Principle of Legal Certainty. This principle is revealed from the binding power of the agreement, namely as the law of the parties.

h. Moral Principles. This principle is seen in the engagement, where a voluntary act of a person does not give him the right to sue the debtor's counter- achievement. This principle is also contained in Article 1339 of the Civil Code. 
i. Proper Principle. This principle is stated in article 1339 of the Civil Code, the principle of propriety here is related to the provisions regarding the contents of the agreement, this principle should be maintained because through this principle the size of the relationship is also determined by the sense of justice in society.

As it is known that the contract was born at the time of the agreement on the main things in the contract, but there are still other things that must be considered, namely the conditions for the validity of the contract as stipulated in Article 1320 of the Civil Code, namely (Miru, 2007):

a. Agreeing those who bind themselves, the agreement of the parties is an absolute element for the occurrence of a contract. This agreement can occur in a number of ways, but the most important is the existence of an offer and acceptance of the offer.

b. The ability to make an engagement, to enter into a contract the parties must be competent. A person is considered capable by law to enter into a contract if the person is 21 years of age and over, but on the other hand someone is considered incompetent to enter into a contract the person is not yet 21 years old, unless he or she has married before 21 years of age.

c. A certain thing, in a contract the object of the agreement must be clear and determined by the parties, the object of the agreement can be in the form of goods or services, but it can also be in the form of not doing something. This particular thing in the contract is called an achievement that can be in the form of goods, expertise or labour, and does not do anything.

d. A lawful reason, the meaning here is that the contents of the contract do not conflict with the laws and regulations.

\section{Legal Consequences to The Party Who Defaults}

Default (Default, nonfulfillment, breach of contract, or breach a promise), according to Fuady. (2001) is the non-performance of achievements or obligations as they should be imposed by the contract on certain parties mentioned in the contract, resulting in losses caused by an error by one or the parties. Default in Article 1243 of the Civil Code, states that: " Reimbursement of costs, losses and interest due to non-fulfilment of an engagement, then begins to be required, if the debtor, after being declared negligent in fulfilling his engagement, continues to neglect it, or if something that must be given or made, only can be given or made, only to be given or made within a grace period that has surpassed."

When viewed from the Restatement of the Law of Contracts (United States of America), defaults or breaches of contracts are only grouped into 2 (two) forms, namely (Salim, 2008):

a. Total breach, namely a state in which the execution of the contract is not possible implemented.

b. Partial breach, which is a condition where the implementation of the agreement is still possible to be carried out.

The statement of negligence as a procedural requirement for determining the moment / time of default is concluded from the substance of Article 1243 of the Civil Code whose complete formulation is as follows: " Reimbursement of costs, losses and interest due to nonfulfilment of an engagement, then becomes obligatory if the debtor after being declared negligent in fulfilling his engagement, continues to neglect it, or if it is something that must be given or made within the grace period specified has surpassed." Referring to Article 1243 Code Civil, can be understood that in procedural but concretely, a default new happens if the debtor or the party who has the obligation to carry out the feat in the contract, otherwise negligent (in mora Stelling, ingbreke Stelling) to carry out his achievements, or with other words, tort exist if the debtor or the party that has the obligation to carry out the feat in the contract are not able to prove that he has been doing in default was on the outside faults because the circumstances 
forced. Thus, " the statement negligent " is a rechtmiddel or attempts law contract (see the Code Civil) to get to the stage of the debtor or the party who were having the obligation to implement the achievements in the contract that stated " default."

If the implementation of the achievement is not specified grace time, then a creditor or a party who has the right to receive achievement in contract, deemed necessary to warn / reprimand that the debtor or the other who has the obligation to implement the achievements in the contract meet its obligations. Reprimand is called also with a subpoena. Conversely, if a grace period execution of achievement has been specified, then in accordance with Article 1238 KUH Civil debtor or the party that has an obligation to implement the achievements in the contract is considered negligent with the passage of time that is specified.

A subpoena must be submitted in writing that explains what are prosecuted, on the basis of what, and at the time when the expected implementation of accomplishment if wants to sue the debtor or the party that has the obligation to carry out the feat in the contract in court. In a lawsuit here, subpoena becoming a tool of evidence that the debtor or the party who has the obligation to carry out the feat in the contract actually been doing in default.

Forms statement negligent who referred also to subpoena regulated in Article 1238 Code Civil, which can be (Syaifuddin, 2012):

a. Letter Command (bevel of sortgelijke certificate), which is an order orally which is delivered through an interpreter seized on the court to the debtor or the party who has the obligation to carry out the feat in the contract, which is tangible copy of a letter of warning. The Supreme Court published a Letter Circular (SEMA) No. 3/1963 which are substantive recognize that derivatives letter tort creditors or parties who have the right to receive achievement to the debtor or the party who has the obligation to carry out the feat in the contract, can be considered a statement negligent;

b. Deed kind, namely the certificate is authentic which is similar to the command of oral interpreter seized on the court was that among others can be letters, telex, telegram, facsimile, and others;

c. In accordance with the agreement stated expressly in the contract itself.

As a result of default by the debtor or parties who have the obligation to carry out the achievements in the contract, it can cause losses for creditors or parties who have the right to receive achievements. legal consequences are all consequences arising from all legal actions undertaken by law subject to the legal object other because of certain events by the law in question has been determined or considered as legal consequences (Dalimunthe, 2017).

The legal consequences for debtors or parties who have an obligation to carry out achievements in contracts, but default is (Syaifuddin, 2012):

a. He must pay compensation for losses suffered by creditors or parties who have the right to receive achievements (see Article 1243 of the Civil Code). The basic principle is that a default requires compensation; reimbursed includes costs, losses and interest. In certain events, in addition to claims for compensation, there may be claims for cancellation of the agreement, exercise of retention rights and advertising rights. Because the name alone is compensation, then logically the amount of compensation is equal to the loss suffered. However, Article 1249 provides an exception, namely unless there is an agreement between the parties regarding the amount of compensation to be paid in the event the debtor defaults. In that case, regardless of the actual amount of the loss to the creditor, the amount as agreed upon or according to the words of Article 1249, "an amount more or less than that amount may not be given " such a promise in an agreement is called, " the promise of compensation / fines " or " schadevergoedings / BOETE beding" 
b. He must accept the termination of the contract accompanied by payment of compensation (vide Article 1267 of the Civil Code).

c. He must accept the risk transfer from the moment the default occurs (vide Article 1237 paragraph (2) of the Civil Code).

d. He must pay court fees if he is sued in court (vide Article 181 paragraph (1) HIR).

In the event that the debtor or party who has the obligation to carry out the performance in the contract but defaults, the creditor or the party who has the right to receive the achievement can choose and file a claim for his rights in court based on the enumeration provisions in Article 1267 jis Article 1266 of the Civil Code, namely (Syaifuddin, 2012):

a. Contract execution;

b. Execution of the contract is accompanied by compensation;

c. Compensation only;

d. Termination of the contract;

e. Termination of the contract is accompanied by compensation.

\section{Conclusion}

The sale and purchase agreement is regulated in Article 1457 to Article 1540 of the Civil Code. In the event of a default in the sale and purchase agreement, if the party who has the obligation to carry out the performance in the contract but defaults is required to pay compensation suffered by the party who has the right to receive the legal basis of achievement contained in article 1243 of the Civil Code, the creditor may request the cancellation of the agreement and can also request the cancellation of the agreement accompanied by the cost of compensation contained in Article 1266-1267 of the Civil Code, must accept the risk transfer from the time of the occurrence of the default contained in Article 1237 paragraph (2) of the Civil Code, and must also pay court fees if prosecuted in the Civil Code. court (vide Article 181 paragraph (1) HIR).

\section{References}

[1] Ahmadi Miru. (2007). Hukum Kontrak dan Perancangan Kontrak. Jakarta: Rajawali Pers.

[2] Badrulzaman, M. D. (2001). Kompilasi hukum perikatan. Bandung: Citra Aditya Bakti.

[3] Dalimunthe, D. (2017). Akibat Hukum Wanprestasi Dalam Perspektif Kitab Undang-Undang Hukum Perdata (Bw). Jurnal AL-MAQASID: Jurnal Ilmu Kesyariahan dan Keperdataan, 3(1), 12-29.

[4] Harefa, B. D. S., \& Tuhana, T. (2016). Kekuatan Hukum Perjanjian Lisan Apabila Terjadi Wanprestasi (Studi Putusan Pengadilan Negeri YOGYAKARTA Nomor44/pdt. g/2015/pn. yyk). Privat Law, 4(2), 164680.

[5] Munir Fuady. (2001). Hukum Kontrak (Dari Sudut Pandang Hukum Bisnis). Bandung: Citra Aditya Bakti.

[6] Prasetyo, H. (2017). Pembaharuan Hukum Perjanjian Sportentertainment Berbasis Nilai Keadilan. Jurnal Pembaharuan Hukum, 4(1), 66.

[7] Salim HS. (2008). Pengantar Hukum Perdata Tertulis (BW). Jakarta: Sinar Grafika.

[8] Subekti, R. (2003). Aspek-aspek Hukum Perjanjian Nasional. Bandung: Citra Aditya Bakti.

[9] Syaifuddin, M. (2012). Hukum Kontrak: Memahami Kontrak dalam Perspektif Filsafat, Teori, Dogmatik, dan Praktik Hukum. Bandung: Mandar Maju.

[10] Yahman. (2014). Karakteristik Wanprestasi dan Tindak Pidana Penipuan. Jakarta: Prenamedia Group. 